\title{
DIAGNOSTICS OF MANAGEMENT CULTURE IN ORDER TO IMPLEMENT THE CONCEPT OF A SOCIALLY RESPONSIBLE COMPANY: THE CASE OF A CONCERN
}

\section{Jolita Vveinhardt, Regina Andriukaitiene}

\section{Introduction}

The benefit of the practical implementation of the company social responsibility (hereinafter - CSR) is unquestionable when society's expectations are considered; however, the boundary between this benefit and the costs of the organization to implement socially responsible behaviour is relatively hard to draw. Although the debate about CSR profitability often emphasized aspect of marketing according to Erhemjamts et al. (2013), controversial issues remain; nevertheless researches show that socially responsible activity is positively associated with investment and organizational strategies; also indirect CSR effect on the company activity results is highlighted through the organization's reputation and customer satisfaction (Galbreath \& Shum, 2012). A pragmatic approach is relevant to organizations in deciding whether to implement the principles of social responsibility in their activities, but the moral values of CSR are no less important for social cohesion in the society and sustainable economic development.

The principle of social responsibility of business organizations reasoned by $\mathrm{H}$. R. Bowen (1953) has remained unchanged so far, despite the frequent criticism and frequent doubts in practice about the benefits for the organization itself (Costas \& Kärreman, 2013). CSR is defined as a social obligation to carry out the policy in making decisions and acting in accordance with the accepted values of society (Maignan \& Ferrell, 2004; Thomas \& Nowak, 2006). Business cherished values and ethics realized in organizational culture are cornerstones of CSR principles (Garavan et al., 2010; Ardichvili, 2013; Pérez \& del Bosque, 2013) relating to the organization and its management culture.

Particularly abundant amount of the scientific works on issues of social responsibility content indicate the timeliness and the importance of this topic. However, the real preparation of organizations to work according to all requirements formulated for corporate social responsibility still raises doubts and induces the analysis of the level of management culture development as an integral part of corporate social responsibility. However, it remains as the unfilled gap in researches that analyse the impact of the management culture upon corporate social responsibility of organizations.

Management culture reflects the level of organization's management system development. It determines how innovations will be introduced to the management of an organization and whether they will be implemented on the whole. Ethics and legislation compliance indicates the level of personal culture and awareness, organic selfawareness organic in the social system. Culture coincides with managerial staff functions and more specifically - the quality of their implementation. Managerial culture is more accepted both by the organization's staff and by clients whose organization-related evaluations distinguishes organizations from each other.

Insufficient knowledge of the links of management culture and CSR may adversely affect the process, during which CSR is being introduced in companies. The problem of the research is posed by the question: what is the attitude of an internal stakeholder - employees - to the management culture aiming at CSR and how can management culture influence CSR?

There are some limitations of this research. In this research, when analyzing coherences of management culture and social responsibility, it is focused on the relationship with employees, their reactions to the organizational system as an interested party. The relationship with the stakeholders outside the organization and 
environmental, philanthropic, etc. activities were not the purpose of this research.

The object of this research is management culture level in order to implement the conception of a socially responsible company.

The aim of the research is to determine the level of management culture in order to implement the conception of a socially responsible company in the case of manufacturing group.

There were used following research methods: the scientific literature analysis and synthesis, a questionnaire survey.

\section{Theoretical Review}

In order to highlight the impact of management culture on CSR, firstly it is necessary to define the content of the management, its components. Therefore, in this part we will discuss the concept of the management culture, its components (categories) and CSR in the context of the internal stakeholder of the organization - the employees, taking into account the goal of the research.

Management culture is an integral part of organization culture. However, in the studies of organizations and their culture sufficient attention is not always paid to the management culture as one of the conditions for change. Management culture is usually addressed by analysing staff work organization, management processes optimization, working conditions formation, organizational design, etc. questions (Zakarevičius, 2004; Vveinhardt, 2011; etc.). There were four components of management culture distinguished, including managerial staff culture, management processes, culture of management organization processes, the culture of the working conditions and culture of documentation system organization. All of these components are closely related to each other.

Management culture components, such as managerial staff culture, were investigated by Furnham and Stringfield (1993), Hales and Mustapha (2000), Subramaniam and Ashkanasy (2001), Raz and Fadlon (2006), Lopez (2006), Bartollas et al. (2007), Pino et al. (2008), Ford and Collison (2011) and others. To sum up the authors' insights, managerial staff culture includes general managerial staff culture, knowledge of management science, staff personal and professional characteristics, leadership style, the ability to manage. All of this has an influence on the quality of the management processes and on the way the management process will be organized.

Processes of management organization were analysed by Mendonca and Kanungo (1990), Pye (1993; 2005), Graetz and Smith (2009), Keevers and Treleaven (2011), Parker and Rees (2013) and others. The organization culture of management processes consists of: rational organization of managerial work, optimal regulation of management processes, modern computerization of management processes, reception of visitors, conduction of meetings, culture of telephone conversations and other factors reflecting other kinds of culture.

Working conditions are discussed in the articles by Blekesaune and Solem (2005), Antonioli et al. (2009), Cremers (2010), Jeong (2012), Parker et al. (2013) and others. The authors distinguish the criteria which are identified as the working conditions of the management culture. Thus, management culture of working conditions consists of work environment (covering the following criteria as workplace interiors, lighting quality, temperature, and cleanness), employment organization, work and rest mode, relaxation options, work safety, socio-psychological microclimate.

Documents of the organization, their management are an integral part of organization of the management processes and ensuring favourable working conditions. Documentation systems are analysed by Briggs and Pate (1996), Jenkins and Erdman (1998), Kalinowski-Jagau (1998) and others. Corporate social responsibility subjects are generally described by Chaudhry and Krishnan (2007), Antal and Sobczak, (2007), Montiel (2008), Aguinis and Glavas, (2012), Blackman et al. (2012) and others. Summarising the insights of various authors it is possible to distinguish the components of the documentation system. Documentation systems' culture includes the following components: document-processing culture, document retrieval and use system, application of modern information technologies, archival documents' storage system.

Various researches focus more on the studies of CSR and corporate culture, changing behaviour, (e.g. Garavan et al., 2010; Ardichvili, 2013). That is, the effect of changing the organization and employees' behaviour is emphasized. However, in the scientific 
literature still there is the gap in analysis of the management culture and social responsibility coherences. That is, distinguishing the management culture. However, there was found that there exists the positive direct connection link between management culture and social responsibility - the raised management culture level enables organizations to enhance social responsibility of the organization (Andriukaitiene, 2013). Therefore, there is a need to analyse the changes of behaviour fostering the links of CSR and management culture in greater detail.

CSR is defined as a social obligation to carry out the decision-making policy and to act in accordance with the accepted values of society (Maignan \& Ferrell, 2004; Thomas \& Nowak, 2006). CSR involves many aspects. According to the definition formulated by WBCSD (1998), CSR is the commitment by business to behave ethically and contribute to economic development while improving the quality of life of the workforce and their families as well as of the local community and society. The renewed definition by the European Commission (2011) notes that when implementing social responsibility companies need processes, integrating social, environmental, ethical, human rights issues and the issues of consumption in the company activity, and a key strategy is close cooperation with stakeholders. Values fostered by business and ethics realized in organizational culture are the cornerstone CSR principles (Garavan et al., 2010; Ardichvili, 2013; Pérez \& del Bosque, 2013). The relationship with internal stakeholders, employees, is revealed through management and management culture. The analysis of scientific experience in relation to social responsibility components shows that social behaviour of organization is analyzed in various aspects. According to Costas and Kärreman (2013), CSR typically stands for corporate responses to ethical, environmental and social issues. Whilst extant research has predominately focused on CSR in relation to external stakeholders and taking a macroinstitutional and/or functionalist perspective. Quite great attention is paid to the investigations of employee's social behaviour. Firstly, the situation of the employees in the organization and consistency within the organization is one of the CSR goals. Secondly, the implementation of CSR principles largely depends on the approval of the staff and the involvement in the processes, therefore, job satisfaction and commitment to the organization are particularly important factors, which depend on the management culture. The issues on employee's intention to leave the job, career change and professional burnout are detected in the following works by the scientists: Li et al. (2010), Young and Corsun (2010), Kuusio et al. (2013), Vveinhardt and Streimikiene (2015), Vveinhardt et al. (forthcoming) and others. The components as uncertainty at work, lack of information, the employee's physical well-being, psychological state are often combined in the analysis of the organization climate, socio-moral, ethical climate, organizational commitment (Kuenzi \& Schminke, 2009; Verdorfer et al., 2013; Wang \& Hsieh, 2013; and others.). Uncertainty at work is analysed in the works of these authors: Choo et al. (2006), Roth (2009), Kallehauge (2010), lack of information work is analysed by Kelly and Shin (2009), Flett (2011) and others. Physical and psychological well-being is discussed in the works of the following scientists: $M$. Brown et al. (2009), Juniper et al. (2012), Kelloway et al. (2013) and others. Bolis et al. (2013) researched ergonomics contribution regarding work in companies in the context of sustainability policies and CSR and noted that sustainable work is believed to be one which improves the organization's performance and fosters professional development as well as workers' health. The social responsibility criticism is formed in the questionnaire used in the study based on Idemudia (2011). Nepotism, favouritism, protectionism is analysed by Wong and Kleiner (1994), Vinton (1998), Abdalla et al. (1998), Padgett and Morris (2005), Arasli and Tumer (2008), Scoppa (2009), Vveinhardt (2013).

Thus, the review of scientific research shows close coherences of management culture and social responsibility concepts that are provided in Table 1. Four categories (dimensions) of the management culture are distinguished in the Table theoretically substantiating the connection with CSR.

The role of the management culture of the organization in the implementation of CSR is generalised and the linkages are demonstrated here. As it has already been mentioned, the dimensions (categories) of management culture are associated with the principled CSR values. For example, the culture of managerial staff 


\section{Tab. 1: Coherences of management culture and social responsibility}

\begin{tabular}{l|l|l}
\multicolumn{1}{c|}{$\begin{array}{c}\text { Management culture } \\
\text { dimensions }\end{array}$} & \multicolumn{1}{|c}{$\begin{array}{c}\text { From management culture } \\
\text { towards CSR }\end{array}$} & \multicolumn{1}{c}{$\begin{array}{c}\text { Relationship with social } \\
\text { responsibility }\end{array}$} \\
\hline Managerial staff culture & Competence, ethics, values & $\begin{array}{l}\text { Managerial staff values and } \\
\text { competences in organizing } \\
\text { corporate processes are significant } \\
\text { both in evaluating organization's } \\
\text { possibilities to develop socially } \\
\text { responsible policies and decision- } \\
\text { making. }\end{array}$ \\
\hline $\begin{array}{l}\text { Management organization } \\
\text { processes of the } \\
\text { organization }\end{array}$ & $\begin{array}{l}\text { Skills of managerial staff to } \\
\text { implement new ideas }\end{array}$ & $\begin{array}{l}\text { Reflects socially responsible } \\
\text { actions and ensures the quality } \\
\text { of the processes' coordination. }\end{array}$ \\
\hline Working conditions & $\begin{array}{l}\text { The state of the management } \\
\text { culture and CSR on the level of } \\
\text { relationships within the organization }\end{array}$ & $\begin{array}{l}\text { Employees - one of the interested } \\
\text { parties, representing organization's } \\
\text { policy in the professional and } \\
\text { personal relationships with external } \\
\text { stakeholders. }\end{array}$ \\
\hline Documentation system & $\begin{array}{l}\text { Organizational conditions to } \\
\text { implement CSR }\end{array}$ & $\begin{array}{l}\text { Database and functional use } \\
\text { of the information on CSR policy } \\
\text { and control as well as accountability } \\
\text { implementation. }\end{array}$ \\
\hline
\end{tabular}

Source: own

is the factor that accumulates and represents CSR values. The perception of company's social responsibility is closely related to the development of management culture (Geva, 2008; Bagdoniene \& Paulaviciene, 2010); it is the organization's strategy and performance management tool and must be applied not only in business but also in any organization (Giziene et al., 2011). In other words, the organization's ability to implement corporate social responsibility values depends on management culture level.

\section{Research Methodology}

After the assessment of the lack of the research of this character, the new, original instrument developed by the authors of the article was used to conduct the research. Having performed the analysis of scientific literature, the research instrument was developed by the way of concepts' operationalization. While developing the instrument, two provisions were considered in advance. First, universal categories - management culture and social responsibility - were identified, without distinction of organizations according to sectors and / or economic activity classification, size, etc. It means that the work with people is viewed in accordance with the humanistic perspective. Second, the defined provision indicates that the object of the research is the management culture, and in case of this research the part of social responsibility becomes the context.

After setting the culture level using the research instrument, it is pursued to diagnose the organization's readiness to become socially responsible. In the questionnaire the part of management culture consists of four categories: managerial staff culture; culture of management processes' organization; management culture of working conditions; documentation system culture. In the questionnaire the part of social responsibility consists of two categories: social behaviour of the organization; employee's social behaviour.

Table 2 presents the first and second stages of the instrument formation, during which the categories were assigned to the parts of management culture and social responsibility (Stage 1), subcategories (Stage 2), statements (Stage 3) are provided. 
Tab. 2: The structure of the questionnaire: parts, categories and subcategories

\begin{tabular}{|c|c|c|c|}
\hline Parts & Categories & Subcategories & $\begin{array}{l}\text { Number of } \\
\text { statements }\end{array}$ \\
\hline \multirow{16}{*}{$\begin{array}{l}\text { Management } \\
\text { culture }\end{array}$} & \multirow{4}{*}{$\begin{array}{l}\text { Managerial staff } \\
\text { culture }\end{array}$} & General level of managerial staff culture & 7 \\
\hline & & Level of management science knowledge & 5 \\
\hline & & $\begin{array}{l}\text { Employees' personal and subject characteristics, } \\
\text { leadership style }\end{array}$ & 7 \\
\hline & & $\begin{array}{l}\text { Level of the ability to manage (managerial art) } \\
\text { level }\end{array}$ & 9 \\
\hline & \multirow{4}{*}{$\begin{array}{l}\text { Culture } \\
\text { of management } \\
\text { processes } \\
\text { organization }\end{array}$} & Optimal management of the regulatory processes & 7 \\
\hline & & Managerial work rational organization & 5 \\
\hline & & $\begin{array}{l}\text { Level of modern management processes' } \\
\text { computerization }\end{array}$ & 5 \\
\hline & & $\begin{array}{l}\text { Customers adoption, meeting conduction, } \\
\text { telephone conversations culture }\end{array}$ & 7 \\
\hline & \multirow{4}{*}{$\begin{array}{l}\text { Management } \\
\text { culture of working } \\
\text { conditions }\end{array}$} & $\begin{array}{l}\text { Working environment level (interior, lighting, } \\
\text { temperature, cleanliness, etc.) }\end{array}$ & 9 \\
\hline & & Workplace organization level & 6 \\
\hline & & Labour and rest mode, relaxation possibilities & 6 \\
\hline & & Work safety, socio-psychological microclimate & 6 \\
\hline & \multirow{4}{*}{$\begin{array}{l}\text { Documentation } \\
\text { system culture }\end{array}$} & Document-processing culture & 6 \\
\hline & & Optimal document search and delivery system & 5 \\
\hline & & Rational use of modern information technologies & 8 \\
\hline & & Rational archival storage system & 6 \\
\hline \multirow{10}{*}{$\begin{array}{l}\text { Social } \\
\text { responsibility }\end{array}$} & \multirow{4}{*}{$\begin{array}{l}\text { Organizations } \\
\text { social } \\
\text { behaviour }\end{array}$} & Responsibility in the market (2 subcategories) ${ }^{\star}$ & 11 \\
\hline & & Environmental responsibility & 7 \\
\hline & & Responsibility in relations with employees & 7 \\
\hline & & Responsibility in relations with society & 6 \\
\hline & \multirow{6}{*}{$\begin{array}{l}\text { Employee } \\
\text { social } \\
\text { behaviour }\end{array}$} & Intentions to leave the job & 6 \\
\hline & & Uncertainty and lack of information at work & 6 \\
\hline & & $\begin{array}{l}\text { Physical and psychological well-being of } \\
\text { employees }\end{array}$ & 5 \\
\hline & & My comments about the organization & 5 \\
\hline & & Corruption, nepotism, favouritism & 10 \\
\hline & & Social responsibility criticism: staff attitude & 10 \\
\hline In total & 6 & 26 & 177 \\
\hline
\end{tabular}

* Services and their quality; consumer information, health and safety. 
In this part of the instrument management culture subcategories comprise 104 statements. Social responsibility subcategory includes 73 statements. As it is seen in Table 2, the number of statements in subcategories is spread quite evenly. The average of management culture part statements in the subcategory - 26 (minimum number of statements is 24 , the maximum number of statements 28 statements). Two categories comprising the part of social responsibility cover 31 and 42 statements. When analyzing the categories and subcategories in respect of the volume of parts, their disparity is based on that social responsibility part inevitably had to include two major categories of social behaviour: the employee and the organization. The minimum number of the statements in the subcategory is 5 . Throughout the questionnaire there are six 5 -step test length subcategories. The maximum number of statements in the subcategory is 9-11. There are five subcategories of such length in the questionnaire. SPSS 21 software package was used to calculate the data.

\section{Organization of the Research}

Questionnaire survey was carried out in 2013 using the questionnaire 'Determination of management culture level for the implementation of the conception of socially responsible companies'. The reliability of the questionnaire was tested in the pilot research with a smaller sample (Andriukaitiene, 2013). Both the pilot research (Cronbach's alpha coefficient of subcategories of the part of the management culture of the questionnaire ranges from 0.75 (the lowest) to 0.9 (the highest), Cronbach's alpha of subcategories of the part of social responsibility of the questionnaire ranges from 0.92 to 0.95 ) and the research of this case (Cronbach's alpha coefficient of subcategories of the part of the management culture of the questionnaire ranges from 0.66 to 0.86 , Cronbach's alpha of subcategories of the part of social responsibility - from 0.62 to 0.86 . As one can see, in the case of different samples the values of the coefficient vary slightly) have high psychometric characteristics.

In order to perform the research one of the concerns that registered its activity in Lithuania and declared the aim to become socially responsible, the main activity of which is manufacturing services, was chosen. However, the concern is on the initial stage of the implementation of CSR, when the analysis of the present situation is carried out. The concern was established in 1998; hence its lifetime for this day is 15 years. During the period of the research 885 employees worked in the concern, 806 respondents, i.e. 91 percent of the concern employees participated in the survey and that permits to assert that sample is representative and reflects the population. The concern wished to remain anonymous, so this article does not mention its name.

\section{Results of the Research}

The respondents were categorized according to: the divisions of companies' group, currently held positions, work experience, age, gender, and education. All results of demographic characteristics of the employees are presented in Table 3.

From the results provided in Table 3 it is seen that the production divisions are represented by 92.06 percent of the employees. In respect of the positions certain distribution is evident; thus it is natural that the largest share of production divisions are occupied by the ordinary workers $(80.27 \%)$. Thus by indicating their positions $19.73 \%$ of the respondents identified that take certain level of managerial positions, but in tagging the division it is clear that some managers indicated the administration, others - production. Consequently in this case at first glance it may seem that there is a discrepancy between the first (division) and the second (position) position, but this is not so. The analysis of the respondents' work experience revealed the tendency that the most abundant number of the employees works up to 5 years (i.e. up to 1 year $-41.3 \%$, from 1 to 5 years $-40.45 \%$ ) in the concern. The percentage of the long-working employees is not big; in general it compiles $18.25 \%$. However, the characteristic of work experience compared with the characteristic of employees' age shows that there is no direct coherence between them - independently of the age group, the number of the respondents identified in all age groups is more or less equal. Thus it cannot be assumed that the employees working for the shorter period are just after graduation, young people. The distribution of the respondents by gender shows the clear dominance of the feminine gender $(67.37 \%)$, which shows that the female workforce is more acceptable in the concern production processes. The analysis of education of the employees shows that $25.43 \%$ 
Tab. 3: The results of demographic characteristics of the employees

\begin{tabular}{|c|c|c|c|}
\hline \multicolumn{2}{|r|}{ Characteristics } & Frequency & $\%$ \\
\hline \multirow{3}{*}{ Division } & Administration & 64 & 7.94 \\
\hline & Production & 742 & 92.06 \\
\hline & In total & 806 & 100.00 \\
\hline \multirow{6}{*}{ Position } & Ordinary employee & 647 & 80.27 \\
\hline & Administrative employee & 112 & 13.90 \\
\hline & Lowest level manager & 26 & 3.23 \\
\hline & Middle level manager & 16 & 1.98 \\
\hline & Top-level manager & 5 & 0.62 \\
\hline & In total & 806 & 100.00 \\
\hline \multirow{5}{*}{ Seniority } & Up to 1 year & 333 & 41.30 \\
\hline & $2-5$ years & 326 & 40.45 \\
\hline & $6-10$ years & 124 & 15.40 \\
\hline & $11-15$ years & 23 & 2.85 \\
\hline & In total & 806 & 100.00 \\
\hline \multirow{7}{*}{ Age } & $18-23$ & 142 & 17.62 \\
\hline & 24-29 & 176 & 21.84 \\
\hline & $30-39$ & 190 & 23.57 \\
\hline & $40-49$ & 194 & 24.07 \\
\hline & 50 - to retirement age & 103 & 12.78 \\
\hline & The retirement age & 1 & 0.12 \\
\hline & In total & 806 & 100.00 \\
\hline \multirow{3}{*}{ Gender } & Man & 263 & 32.63 \\
\hline & Woman & 543 & 67.37 \\
\hline & In total & 806 & 100.00 \\
\hline \multirow{7}{*}{$\begin{array}{l}\text { Education of the } \\
\text { employees }\end{array}$} & University education & 114 & 14.14 \\
\hline & Higher non-university & 91 & 11.29 \\
\hline & College & 134 & 16.62 \\
\hline & Professional & 209 & 25.93 \\
\hline & Secondary & 232 & 28.80 \\
\hline & Primary & 26 & 3.22 \\
\hline & In total & 806 & 100.00 \\
\hline
\end{tabular}

of them have higher education. Compared with the positions it is obvious that not all managing persons have higher education (as it was mentioned above there are $19.73 \%$ of the managing persons); therefore it is possible to affirm that the managers working in the lowest production divisions' levels might have college education (as well as a number of the ordinary workers).

Table 4 presents the results that were tested by the Student's criterion (t-test). The minus sign at z-estimate indicator notes the negative situation because all questionnaire statements were coded positively. 


\begin{tabular}{l|c|c|c|c}
\multicolumn{1}{c|}{ Subscales } & Administration & Production & \multicolumn{2}{|c}{$\begin{array}{c}\text { t-test screening } \\
\text { results }\end{array}$} \\
\cline { 4 - 5 } & & $\mathbf{N}=\mathbf{6 4 )}$ & $\mathbf{t}=\mathbf{7 4 2})$ & $\mathbf{p}$ \\
\hline Managerial staff culture & 0.12 & -0.19 & 2.382 & $\mathbf{0 . 0 1 7 ^ { * }}$ \\
\hline $\begin{array}{l}\text { Culture of management processes' } \\
\text { organization }\end{array}$ & -0.14 & 0.06 & -2.296 & $\mathbf{0 . 0 2 2}^{*}$ \\
\hline Management culture of working conditions & 0.61 & -0.17 & 6.334 & $\mathbf{0 . 0 0 0}^{* *}$ \\
\hline Documentation system culture & 0.27 & -0.23 & 4.539 & $\mathbf{0 . 0 0 0}^{* *}$ \\
\hline Organization social behaviour & 0.46 & -0.03 & 3.955 & $\mathbf{0 . 0 0 0}^{\text {** }}$ \\
\hline Employee's social behaviour & 0.78 & 0.06 & 5.730 & $\mathbf{0 . 0 0 0}^{\text {** }}$ \\
\hline
\end{tabular}

* Statistical significance level $\alpha=0.05 ;{ }^{* *}$ statistical significance level $\alpha=0.01$

\section{Tab. 5: Management culture and social responsibility in relation to the concern staff}

\begin{tabular}{|c|c|c|c|c|c|c|c|}
\hline \multirow{2}{*}{ Subscales } & \multirow{2}{*}{$\begin{array}{l}\text { Ordinary } \\
\text { employee } \\
(\mathrm{N}=647)\end{array}$} & \multirow{2}{*}{$\begin{array}{c}\text { Admini- } \\
\text { stration } \\
\text { employee } \\
(\mathrm{N}=112)\end{array}$} & \multirow{2}{*}{$\begin{array}{l}\text { Lowest level } \\
\text { manager } \\
(\mathrm{N}=26)\end{array}$} & \multirow{2}{*}{$\begin{array}{l}\text { Middle level } \\
\text { manager } \\
(\mathrm{N}=16)\end{array}$} & \multirow{2}{*}{$\begin{array}{c}\text { The highest } \\
\text { level } \\
\text { manager } \\
(\mathrm{N}=5)\end{array}$} & \multicolumn{2}{|c|}{$\begin{array}{c}\text { ANOVA } \\
\text { screening results }\end{array}$} \\
\hline & & & & & & $F$ & $p$ \\
\hline $\begin{array}{l}\text { Managerial staff } \\
\text { culture }\end{array}$ & -0.23 & 0.06 & -0.05 & 0.18 & 2.14 & 9.803 & $0.000^{* *}$ \\
\hline $\begin{array}{l}\text { Culture of } \\
\text { management } \\
\text { processes' } \\
\text { organization }\end{array}$ & 0.05 & -0.01 & 0.19 & -0.02 & 0.78 & 1.992 & 0.094 \\
\hline $\begin{array}{l}\text { Management culture } \\
\text { of working conditions }\end{array}$ & -0.22 & 0.32 & 0.10 & 0.64 & 1.73 & 15.866 & $0.000^{* *}$ \\
\hline $\begin{array}{l}\text { Documentation system } \\
\text { culture }\end{array}$ & -0.30 & 0.16 & 0.03 & 0.66 & 1.77 & 20.106 & $0.000^{* *}$ \\
\hline $\begin{array}{l}\text { Organization social } \\
\text { behaviour }\end{array}$ & -0.06 & 0.26 & -0.03 & 0.57 & 2.21 & 11.342 & $0.000^{* *}$ \\
\hline $\begin{array}{l}\text { Employee's social } \\
\text { behaviour }\end{array}$ & -0.01 & 0.60 & 0.25 & 0.91 & 2.18 & 19.382 & $0.000^{* *}$ \\
\hline
\end{tabular}

${ }^{*}$ statistical significance level $\alpha=0.05 ;{ }^{* *}$ statistical significance level $\alpha=0.01$

Source: own

The aspects of management culture and social responsibility vary depending on what organization's subdivision the respondents work in. It was tested by the Student's criterion (t-test). It is important that when analyzing the management culture and social responsibility in respect of all divisions of the concern the statistically significant differences were determined in absolutely all subscales. The results show that there is a significant difference in grouping the respondents into two largest categories - administration and production staff. The production staff, unlike executives, has a different and unfavourable attitude 
towards the cultural elements representing the management staff and the demonstrated values of social responsibility. This shows that the actions of the managing personnel are disapproved, or they can be treated not as expected. In this situation one cannot expect an efficient interaction of managing personnel and the employees. The more so as the unevenness of evaluations of culture of organisation of management processes are particularly highlighted. The differences conformable to the current positions held are presented in Table 5.

In many cases the aspects of management culture and social responsibility are different depending on the positions held by the employees. The higher the position is, the more favourable the evaluation is. This again confirms the fact that has been described above that there is a huge gap between the managers and the staff. Maybe the management doesn't assess the level of its management culture and the real situation of the CSR values within organization adequately. Ordinary employees evaluated management culture worst in accordance with almost all the components, and they exceptionally critically evaluated the components of social responsibility. The tests were carried out by using the univariate dispersive analysis One-way ANOVA. According to Tukey HSD test, the statistically significant differences were identified between the z-estimates of the top-level managers and the staff of other positions. The statistically significant differences were not identified on the analysed issue only in the subscale of the culture of management processes organization. It is obvious that the assessments of organization's managerial staff policy development are not adequate to the subordinates' reactions. The middle link staff - is not the exception. The data presented in Tables 6,7 and 8 provide significant observations to managerial system by exploring the reasons for the gap.

\section{Tab. 6: Management culture and social responsibility in relation to the work experience of the concern employees}

\begin{tabular}{|c|c|c|c|c|c|c|c|}
\hline \multirow[t]{2}{*}{ Subscales } & \multirow{2}{*}{$\begin{array}{l}\text { Up to } 1 \\
\text { year } \\
(N=333)\end{array}$} & \multirow{2}{*}{$\begin{array}{l}2-5 \text { years } \\
(\mathrm{N}=326)\end{array}$} & \multirow{2}{*}{$\begin{array}{c}6-10 \text { years } \\
(N=124)\end{array}$} & \multirow{2}{*}{$\begin{array}{c}11-15 \\
\text { years } \\
(\mathrm{N}=21)\end{array}$} & \multirow{2}{*}{$\begin{array}{c}\text { More than } \\
16 \text { years } \\
(\mathrm{N}=2)\end{array}$} & \multicolumn{2}{|c|}{$\begin{array}{l}\text { ANOVA screening } \\
\text { results }\end{array}$} \\
\hline & & & & & & $F$ & $p$ \\
\hline Managerial staff culture & -0.13 & -0.19 & -0.30 & 0.28 & 1.42 & 3.085 & $0.016^{*}$ \\
\hline $\begin{array}{l}\text { Culture of management } \\
\text { processes' organization }\end{array}$ & 0.05 & 0.07 & -0.04 & 0.08 & 0.74 & 1.139 & 0.337 \\
\hline $\begin{array}{l}\text { Management culture } \\
\text { of working conditions }\end{array}$ & -0.21 & -0.08 & -0.03 & 0.50 & 0.93 & 3.828 & $0.004^{* *}$ \\
\hline $\begin{array}{l}\text { Documentation system } \\
\text { culture }\end{array}$ & -0.29 & -0.15 & -0.13 & 0.18 & 0.62 & 2.919 & $0.021^{*}$ \\
\hline Organization social behaviour & -0.04 & 0.05 & -0.08 & 0.63 & 0.93 & 3.299 & $0.011^{*}$ \\
\hline Employee's social behaviour & 0.06 & 0.14 & 0.09 & 0.56 & 1.26 & 2.115 & 0.077 \\
\hline
\end{tabular}

* statistical significance level $\alpha=0.05 ;{ }^{* *}$ statistical significance level $\alpha=0.01$

In most cases the aspects of management culture and social responsibility assessment vary depending on work experience in the workplace. The tests were carried out by using the univariate dispersive analysis One-way ANOVA. According to Tukey HSD test, the statistically significant differences were identified between the z-estimates of the employees with the largest work experience (more than
16 years) and the employees with less work experience. However, it should be noted that this organization has only two employees with most solid work experience. The length of service of more than a half of the employees in the organisation is to up to five years. Given that the organization has been working for more than ten years, this shows a significant staff turnover, that can be influenced by both 


\begin{tabular}{|c|c|c|c|c|c|c|c|}
\hline $\begin{array}{l}\text { Managemer } \\
\text { of the conc }\end{array}$ & $\begin{array}{l}\text { Iture anc } \\
\text { staff }\end{array}$ & social res & pponsibilit & $y$ in rela & $\mathrm{n}$ to the & & \\
\hline \multirow[t]{2}{*}{ Subscales } & \multirow{2}{*}{$\begin{array}{c}18-23 \\
\text { years } \\
(\mathbf{N}=142)\end{array}$} & \multirow{2}{*}{$\begin{array}{c}24-29 \\
\text { years } \\
(N=176)\end{array}$} & \multirow{2}{*}{$\begin{array}{c}30-39 \\
\text { years } \\
(\mathrm{N}=190)\end{array}$} & \multirow{2}{*}{$\begin{array}{c}40-49 \\
\text { years } \\
(\mathrm{N}=194)\end{array}$} & \multirow{2}{*}{$\begin{array}{c}50 \text { y.- to } \\
\text { retire- } \\
\text { ment } \\
\text { age } \\
(\mathrm{N}=104)\end{array}$} & \multicolumn{2}{|c|}{$\begin{array}{l}\text { ANOVA scree- } \\
\text { ning results }\end{array}$} \\
\hline & & & & & & $\mathbf{F}$ & p \\
\hline Managerial staff culture & -0.31 & -0.15 & -0.09 & -0.11 & -0.22 & 1.265 & 0.282 \\
\hline $\begin{array}{l}\text { Culture of management } \\
\text { processes' organization }\end{array}$ & 0.01 & -0.05 & 0.05 & 0.12 & 0.13 & 1.995 & 0.093 \\
\hline $\begin{array}{l}\text { Management culture of } \\
\text { working conditions }\end{array}$ & -0.41 & -0.19 & -0.01 & 0.01 & 0.06 & 5.812 & $0.000^{* *}$ \\
\hline $\begin{array}{l}\text { Documentation system } \\
\text { culture }\end{array}$ & -0.40 & -0.13 & -0.20 & -0.11 & -0.16 & 2.920 & $0.020^{*}$ \\
\hline $\begin{array}{l}\text { Organization social } \\
\text { behaviour }\end{array}$ & -0.24 & -0.05 & 0.09 & 0.11 & 0.11 & 3.651 & $0.006^{* *}$ \\
\hline $\begin{array}{l}\text { Employee's social } \\
\text { behaviour }\end{array}$ & -0.19 & 0.15 & 0.28 & 0.19 & 0.04 & 5.367 & $0.000^{* *}$ \\
\hline
\end{tabular}

* statistical significance level $\alpha=0.05 ;{ }^{* *}$ statistical significance level $\alpha=0.01$

the level of the management culture and social behaviour of the organization. The management culture and social responsibility in relation to the work experience of the concern staff reveal the statistically significant differences in the larger part of the subscales, i.e. the significant differences were not identified only in two subscales (culture of management processes' organization and employee's social behaviour).

Judging by the number of respondents, the composition of the staff of the concern by age allows expecting that the majority have gained professional and life experience, therefore, their evaluations are reasonable. The fact that no statistically significant differences have been found in the categories of managerial staff culture and the culture of organization of management processes should be noted. In all cases the aspects of management culture and social responsibility differ depending on staff age. The characteristics of management working conditions, documentation system culture, social behaviour of the organization and employee were distinguished. The tests were carried out by using the univariate dispersive analysis One-way ANOVA. According to Tukey HSD test, the statistically significant differences were identified between the z-estimates of the youngest employees (18-23 years old) and middle-aged employees. The negative ratio of managerial actions' efficiency with certain age groups was revealed.

Since this is a manufacturing organization, primary, secondary and vocational education predominates. This had a significant impact on the provided evaluations of components of management culture and social responsibility. The aspects of management culture and social responsibility differ depending on staffeducation. According to Tukey HSD test, the statistically significant differences were identified among the z-estimates of the groups (with higher, college and professional as well as secondary/ primary education). The tests were carried out by using the univariate dispersive analysis Oneway ANOVA. It shows the influence of education on the acceptance of managerial actions and the changes in managerial culture. In addition, it is the differences in education can become one of the problem of the gap between different groups of staff and internal communication when feedback is ensured insufficiently.

In some cases the aspects of management culture and social responsibility differ depending on staff gender. It was tested by the Student's criterion (t-test). As Table 9 shows, the most statistically significant differences were identified in the following subscales: management culture of working conditions, documentation system culture, and employee's social behaviour. 


\begin{tabular}{|c|c|c|c|c|c|c|}
\hline $\begin{array}{l}\text { Management culture } \\
\text { of the concern staff }\end{array}$ & d social $r$ & esponsi & ity in re & ion to & cation & \\
\hline \multirow{2}{*}{ Subscales } & \multirow{2}{*}{$\begin{array}{l}\text { Higher } \\
(\mathrm{N}=205)\end{array}$} & \multirow{2}{*}{$\begin{array}{c}\text { College } \\
(N=134)\end{array}$} & \multirow{2}{*}{$\begin{array}{c}\text { Professi- } \\
\text { onal } \\
(\mathrm{N}=209)\end{array}$} & \multirow{2}{*}{\begin{tabular}{|c} 
Secon- \\
dary I \\
primary \\
$(\mathrm{N}=\mathbf{2 5 8})$
\end{tabular}} & \multicolumn{2}{|c|}{$\begin{array}{c}\text { ANOVA screening } \\
\text { results }\end{array}$} \\
\hline & & & & & $\mathbf{F}$ & $\mathbf{p}$ \\
\hline Managerial staff culture & 0.07 & -0.09 & -0.28 & -0.30 & 6.949 & $0.0001^{* *}$ \\
\hline $\begin{array}{l}\text { Culture of management processes' } \\
\text { organization }\end{array}$ & 0.05 & 0.15 & 0.11 & -0.06 & 3.904 & $0.009^{\star *}$ \\
\hline $\begin{array}{l}\text { Management culture of working } \\
\text { conditions }\end{array}$ & 0.21 & -0.11 & -0.11 & -0.35 & 13.192 & $0.000^{* *}$ \\
\hline Documentation system culture & 0.06 & -0.06 & -0.25 & -0.41 & 13.968 & $0.000^{* *}$ \\
\hline Organization social behaviour & 0.21 & 0.10 & 0.00 & -0.19 & 7.298 & $0.000^{* *}$ \\
\hline Employee's social behaviour & 0.51 & 0.24 & -0.01 & -0.16 & 21.424 & $0.000^{* *}$ \\
\hline
\end{tabular}

* statistical significance level $\alpha=0.05 ;{ }^{* *}$ statistical significance level $\alpha=0.01$

Source: own

\begin{tabular}{|c|c|c|c|c|c|}
\hline Tab. 9: & $\begin{array}{l}\text { Management culture and social } \\
\text { gender }\end{array}$ & onsibility & relation & le co & staff \\
\hline \multirow{2}{*}{\multicolumn{2}{|c|}{ Subscales }} & \multirow{2}{*}{$\begin{array}{c}\text { Man } \\
(\mathrm{N}=\mathbf{2 6 3})\end{array}$} & \multirow{2}{*}{$\begin{array}{l}\text { Woman } \\
(\mathrm{N}=543)\end{array}$} & \multicolumn{2}{|c|}{$\begin{array}{l}\text { t-test screening } \\
\text { results }\end{array}$} \\
\hline & & & & $\mathbf{t}$ & p \\
\hline \multicolumn{2}{|c|}{ Managerial staff culture } & -0.09 & -0.20 & 1.559 & 0.119 \\
\hline \multicolumn{2}{|c|}{ Culture of management processes' organization } & 0.07 & 0.04 & 0.659 & 0.510 \\
\hline \multicolumn{2}{|c|}{ Management culture of working conditions } & 0.00 & -0.16 & 2.080 & $0.038^{*}$ \\
\hline \multicolumn{2}{|c|}{ Documentation system culture } & -0.07 & -0.25 & 2.774 & $0.006^{* *}$ \\
\hline \multicolumn{2}{|c|}{ Organization's social behaviour } & 0.09 & -0.03 & 1.646 & 0.100 \\
\hline \multicolumn{2}{|c|}{ Employee's social behaviour } & 0.27 & 0.04 & 3.185 & $0.002^{* *}$ \\
\hline
\end{tabular}

* statistical significance level $\alpha=0.05 ;{ }^{* *}$ statistical significance level $\alpha=0.01$

Source: own

No statistically significant differences have been found in the categories of management culture, culture of organization of management processes, social behaviour of the organization. The evaluations on the gender remain the subject of discussion because women more often tend to react to the situation and interpret it more openly than men in sociological researches (Zukauskas \& Vveinhardt, 2009). However, the estimates of components of managerial staff culture, culture of organization of management processes and social behaviour of the organization are distinguished both when measured by gender, and according to other parameters. To sum up briefly, we can state that the concern is not mature for efficient implementation of CSR ideas and the weakly-developed culture of management and the ability to properly organize processes can be considered as the cause. The level of the management culture also influences quite critical evaluations of the components representing CSR.

\section{Conclusions}

The state of the management culture of the organization and preparedness of the organization to become a socially responsible organization (to implement CSR principles) are two complex variables that are dependent on each other. The concept of management culture is developed and the relationship 
between the management culture and CSR is analysed in the study. According to the authors of the article, before the implementation of CSR in the activities of the company, first it is necessary to assess the state of the management culture, which gives primary information to CSR implementation strategy, taking into account the situation of the specific organization. The organizations that have a high level of management culture are ready to become socially responsible. The employee reaction to the culture of the organization can be considered as a kind of litmus.

When the employees estimate social responsibility activities negatively and the administration positively the following assumptions are possible: the social responsibility program is implemented formally, there are no feedback mechanisms. Hence, there is no effective internal auditing system of social responsibility, which should be ensured by management culture. It is diagnosed that social responsibility does not become an inseparable part of organizational culture. It highlights the coherences of management culture and social responsibility. As the systematic approach, which would embrace the practice of management culture and social responsibility, the danger for the quality of realized managerial actions emerges. The employees' reaction to the managerial culture is an important signal that induces the changes in the implementation of the social responsibility program to primarily initiate in managerial staff level. In addition, in implementing the social responsibility policy it is necessary to take into account the sociodemographic and human resources as well as psychological climate that can improve the interaction between the managerial staff and subordinates.

If organizations are not ready to become socially responsible or social responsibility is not axiologically accepted, they can only imitate socially responsible activities, but it will not become an organic part of the management culture. In this case, there should be a natural shortage of consistency in actions and suggestive power in respect of both employees and the society (customers, partners, communities). This kind of imitation can enhance the employees' dissatisfaction and internal conflict. So the internal consistency of the organization, as one of the key values of the CSR may remain unachieved. Future studies should continue to develop the methodologies of the management culture, social behaviour of the company and social behaviour of employees.

\section{References}

Abdalla, H. F., Maghrabi, A. S., \& Raggad, B. G. (1998). Assessing the perceptions of human resource managers toward nepotism: A cross-cultural study. International Journal of Manpower, 19(8), 554-570. doi:10.1108/01437729810242235.

Aguinis, H., \& Glavas, A. (2012). What we know and don't know about corporate social responsibility: a review and research agenda. Journal of Management, 38(4), 932-968. doi:10.1177/0149206311436079.

Andriukaitiene, R. (2013). Vadybos kultūros ir socialinio atsakingumo sąsajos savivaldos organizacijoje. Management Theory and Studies for Rural Business and Infrastructure Development, 35(3), 339-346.

Antal, A. B., \& Sobczak, A. (2007). Corporate social responsibility in France a mix of national traditions and international influences. Business \& Society, 46(1), 9-32. doi:10.1177/0007650306293391.

Antonioli, D., Mazzanti, M., \& Pini, P. (2009). Innovation, Working Conditions and Industrial Relations: Evidence for a Local Production System. Economic and Industrial Democracy, 30(2), 157-181. doi:10.1177/0143831X09102418.

Arasli, H., \& Tumer, M. (2008). Nepotism, Favoritism and Cronyism: A study of their effects on job stress and job satisfaction in the banking industry of north Cyprus. Social behaviour and personality, 36(9), 1237-1250. doi:10.2224/ sbp.2008.36.9.1237.

Ardichvili,A. (2013). The Role of HRD in CSR, Sustainability, and Ethics: A Relational Model. Human Resource Development Review, 12(4), 456-473. doi:10.1177/1534484313478421.

Bagdoniene, D., \& Paulaviciene, E. (2010). Socialinès atsakomybès ir organizacijos vadybos sistemos integravimas. Ekonomika ir vadyba. Economics \& Management, 15, 366-373.

Bartollas, C., Miller, S. J., \& Dinitz, S. (2007). Managerial Styles and Institutional Control. Youth Violence and Juvenile Justice, 5(1), 57-70. doi:10.1177/1541204006295165.

Blackman, D., Kennedy, M., \& Quazi, A. (2012). Corporate social responsibility and 
individual resistance: learning as the missing link in implementation. Management Learning, 44(3), 237-252. doi:10.1177/1350507612444392.

Blekesaune, M., \& Solem, P. E. (2005). Working Conditions and Early Retirement: A Prospective Study of Retirement Behaviour. Research on Aging, 27(1), 3-30. doi:10.1177/0164027504271438.

Bolis, I., Morioka, S. N., Brunoro, C. M., \& Sznelwaroi, I. (2013). Sustainability policies and Corporate Social Responsibility (CSR): Ergonomics contribution regarding work in companies. Proceedings of the Human Factors and Ergonomics Society Annual Meeting, 57(1), 1080-1084. doi:10.1177/1541931213571240.

Bowen, H. R. (1953). Social Responsibilities of the Businessman. New York: Harper \& Row.

Briggs, S., \& Pate, E. W. (1996). Successful Implementation of Computerized Documentation in Home Health Care. Home Health Care Management \& Practice, 8(3), 3644. doi:10.1177/108482239600800309.

Brown, M., Metz, I., Cregan, C., \& Kulik, C. T. (2009). Irreconcilable differences? Strategic human resource management and employee well-being. Asia Pacific Journal of Human Resources, 47(3), 270-294. doi:10.1177/1038411109106859.

Chaudhry, K., \& Krishnan, V. R. (2007). Impact of corporate social responsibility and transformational leadership on brand community: an experimental study. Global business review, 8(2), 205-220. doi:10.1177/097215090700800202.

Choo, C. W., Furness, C., Paquette, S., van den Berg, H., Detlor, B., Bergeron, P., \& Beaton, L. (2006). Working with information: information management and culture in a professional services organization. Journal of Information Science, 32(6), 491-510. doi:10.1177/0165551506068159.

Costas, J., \& Kärreman, D. (2013). Conscience as control - managing employees through CSR. Organization, 20(3), 394-415. doi: $10.1177 / 1350508413478584$.

Cremers, J. (2010). Rules on working conditions in Europe: Subordinated to freedom of services? European Journal of Industrial Relations, 16(3), 293-306. doi:10.1177/0959680110375138.

Erhemjamts, O., Li, Q., \& Venkateswaran, A. (2013). Corporate Social Responsibility and Its Impact on Firms' Investment Policy, Organizational Structure, and Performance.
Journal of Business Ethics, 118(2), 395-412. doi:10.1007/s10551-012-1594-X.

European Commission. (2011). Communication from the Commission to the European Parliament, the Council, the European Economic and Social Committee and the Committee of the Regions a renewed EU Strategy 2011-14 for Corporate Social Responsibility. Brussels: EC.

Flett, A. (2011). Information Management Possible?: Why is information management so difficult? Business Information Review, 28(2), 92-100. doi:10.1177/0266382111411066.

Ford, J., \& Collison, D. (2011). In search of the perfect manager? Worklife balance and managerial work. Work, Employment \& Society, 25(2), 257-273. doi:10.1177/0950017011398895.

Furnham, A., \& Stringfield, P. (1993). Personality and Occupational Behaviour: MyersBriggs Type Indicator Correlates of Managerial Practices in Two Cultures. Human Relations, 46(7), 827-848. doi:10.1177/001872679304600703.

Galbreath, J., \& Shum, P. (2012). Do customer satisfaction and reputation mediate the CSR-FP link? Evidence from Australia. Australian Journal of Management, 37(2), 211-229. doi:10.1177/0312896211432941.

Garavan, T. N., Heraty, N., Rock, A., \& Dalton, E. (2010). Conceptualizing the Behavioral Barriers to CSR and CS in Organizations: A Typology of HRD Interventions. Advances in Developing Human Resources, 12(5), 587-613. doi:10.1177/1523422310394779.

Geva, A. (2008). Three Models of Corporate Social Responsibility: Interrelationships between Theory, Research, and Practice. Business and Society Review, 113(1), 1-41. doi:10.1111/j.1467-8594.2008.00311.x.

Giziene, V., Palekiene, O., \& Simanaviciene, Z. (2011). Valstybès socialinè atsakomybè žinių ekonomikos kontekste. Ekonomika ir vadyba. Economics \& Management, 16, 485-492.

Graetz, F., \& Smith, A. C. T. (2009). Duality Theory and Organizing Forms in Change Management. Journal of Change Management, 9(1), 9-25. doi:10.1080/14697010902727146.

Hales, C. P., \& Mustapha, N. (2000). Commonalities and variations in managerial work: a study of middle managers in Malaysia. Asia Pacific Journal of Human Resources, 38(1), 731-756. doi:10.1177/103841110003800102.

Idemudia, U. (2011). Corporate social responsibility and developing countries moving 
the critical CSR research agenda in Africa forward. Progress in Development Studies, 11(1), 1-18. doi:10.1177/146499341001100101.

Jenkins, J., \& Erdman, K. (1998). WebBased Documentation Systems. Home Health Care Management \& Practice, 10(2), 52-61. doi:10.1177/108482239801000212.

Jeong, I. S. (2012). Working Conditions, Job Perceptions, Job Satisfaction, and Intentions to Stay at the Job for Clinical Research Coordinators in the Republic of Korea. Drug Information Journal, 46(3), 303-312. doi:10.1177/0092861512436841.

Juniper, B., Bellamy, P., \& White, N. (2012). Evaluating the well-being of public library workers. Journal of Librarianship and Information Science, 44(2), 108-117. doi:10.1177/0961000611426442.

Kalinowski-Jagau, K.P.(1998). Organizing and managing development information: a personal view from Germany. Information Development, 14(1), 20-24. doi:10.1177/0266666984239012.

Kallehauge, J. (2010). Stage-driven information seeking process: Value and uncertainty of work tasks from initiation to resolution. Journal of Information Science, 36(2), 242-262. doi:10.1177/0165551509360142.

Keevers, L., \& Treleaven, L. (2011). Organizing practices of reflection: A practicebased study. Management Learning, 42(5), 505-520. doi:10.1177/1350507610391592.

Kelloway, E. K., Weigand, H., McKee, M. C., \& Das, H. (2013). Positive Leadership and Employee Well-Being. Journal of Leadership \& Organizational Studies, 20(1), 107-117. doi:10.1177/1548051812465892.

Kelly, K. R., \& Shin, Y. J. (2009). Relation of Neuroticism and Negative Career Thoughts and Feelings to Lack of Information. Journal of Career Assessment, 17(2), 201-213. doi:10.1177/1069072708329029.

Kuenzi, M., \& Schminke, M. (2009). Assembling Fragments Into a Lens: A Review, Critique, and Proposed Research Agenda for the Organizational Work Climate Literature. Journal of Management, 35(3), 634-717. doi:10.1177/0149206308330559.

Kuusio, H., Heponiemi, T., Vänskä, J., Aalto, A. M., Ruskoaho, J., \& Elovainio, M. (2013). Psychosocial stress factors and intention to leave job: differences between foreignborn and Finnish-born general practitioners. Scandinavian Journal of Public Health, 41(4), 405-411. doi:10.1177/1403494813477248.
Li, J., Fu, H., Hu, Y., Shang, L., Wu, Y., Kristensen, T. S., Mueller, B. H., \& Hasselhorn, H. M. (2010). Psychosocial work environment and intention to leave the nursing profession: Results from the longitudinal Chinese NEXT study. Scandinavian Journal of Public Health, 38(3), 69-80. doi:10.1177/1403494809354361.

Lopez, S. H. (2006). Culture Change Management in Long-Term Care: A ShopFloor View. Politics \& Society, 34(1), 55-80. doi:10.1177/0032329205284756.

Maignan, I., \& Ferrell, O. C. (2004). Corporate Social Responsibility and Marketing: An Integrative Framework. Journal of the Academy of Marketing Science, 32(1), 3-19. doi:10.1177/0092070303258971.

Mendonca, M., \& Kanungo, R. N. (1990). Work Culture In Developing Countries: Implications For Performance Management. Psychology \& Developing Societies, 2(2), 137164. doi:10.1177/097133369000200201.

Montiel, I. (2008). Corporate social responsibility and corporate sustainability: separate pasts, common futures. Organization \& Environment, 21(3), 245-269. doi:10.1177/1086026608321329.

Padgett, M. Y., \& Morris, K.A. (2005). Keeping it „All in the Family:" Does Nepotism in the Hiring Process Really Benefit the Beneficiary? Journal of Leadership \& Organizational Studies, 11(2), 34-44. doi:10.1177/107179190501100205.

Parker, C., \& Rees, J. (2013). Membership growth at a time of union decline: Usdaw, organizing and leadership. Transfer: European Review of Labour and Research, 19(4), 521538. doi:10.1177/1024258913501768.

Parker, V., Andel, R., Nilsen, Ch., \& Kåreholt, I. (2013). The Association between Mid-Life Socioeconomic Position and Health after Retirement - Exploring the Role of Working Conditions. Journal of Aging and Health, 25(5), 863-881. doi:10.1177/0898264313492822.

Pérez, A., \& del Bosque, I. R. (2013). Extending on the Formation Process of CSR Image. Social Marketing Quarterly, 19(3), 156171. doi:10.1177/1524500413489287.

Pino, J. M. R., Gardey, G. S., \& Hagen, I. (2008). When Staff Create the Organisational Culture: A Case Study in the Spanish Emergency Health Care System. Journal of Health Management, 10(2), 163-189. doi:10.1177/097206340801000201.

Pye, A. (1993). "Organizing as Explaining" and the Doing of Managing an Integrative 
Appreciation of Processes of Organizing. Journal of Management Inquiry, 2(2), 157-168. doi:10.1177/105649269322006.

Pye, A. (2005). Leadership and Organizing: Sensemaking in Action. Leadership, 1(1), 31-49. doi:10.1177/1742715005049349.

Raz, A. E., \& Fadlon, J. (2006). Managerial Culture, Workplace Culture and Situated Curricula in Organizational Learning. Organization Studies, 27(2), 165-182. doi:10.1177/0170840605056399.

Roth, W. M. (2009). Radical Uncertainty in Scientific Discovery Work. Science, Technology \& Human Values, 34(3), 313-336. doi:10.1177/0162243907309627.

Scoppa, V. (2009). Intergenerational transfers of public sector jobs: a shred of evidence on nepotism. Public Choice, 141(1), 167-188. doi:10.1007/s11127-009-9444-9.

Subramaniam, N., \& Ashkanasy, N. M. (2001). The Effect of Organisational Culture Perceptions on the Relationship between Budgetary Participation and Managerial Job-Related Outcomes. Australian Journal of Management, 26(1), 35-54. doi:10.1177/031289620102600103.

Thomas, G., \& Nowak, M. (2006). Corporate Social Responsibility: A definition (GSB Working paper 62). Retrieved January 9, 2014, from http://www.iese.edu/research/pdfs/ di-0834-e.pdf.

Verdorfer, A. P., Weber, W. G., Unterrainer, Ch., \& Seyr, S. (2013). The relationship between organizational democracy and socio-moral climate: Exploring effects of the ethical context in organizations. Economic and Industrial Democracy, 34(3), 423-449. doi:10.1177/0143831X12450054.

Vinton, K. L. (1998). Nepotism: an interdisciplinary model. Family Business Review, 11(4), 297-303. doi:10.1111/j.17416248.1998.00297.x.

Vveinhardt, J. (2011). Organizacijos kultūros ir organizacinès kultūros charakteristikos. Management theory and studies for rural business and infrastructure development, 5(29), 221-230.
Vveinhardt, J. (2013). Nepotism in management of the organization: phenomenon discriminating employees. Economy \& Business, 7(3), 223-230.

Vveinhardt, J., \& Streimikiene, D. (2015). The questionnaire for diagnosing mobbing in employees' relationships. Economic Research - Ekonomska Istraživanja, 28(1), 441-466. doi:10.1080/1331677X.2015.1075415.

Vveinhardt, J., Majauskiene, D., \& Valanciene, D. (Forthcoming). Does perceived stress and workplace bullying alter employees' moral decision-making?

Wang, Y. D., \& Hsieh, H. H. (2013). Organizational ethical climate, perceived organizational support, and employee silence: A cross-level investigation. Human Relations, 66(6),783-802. doi:10.1177/0018726712460706.

WBCSD Stakeholder Dialogue on CSR, The Netherlands (1998). Retrieved January 15, 2014, from www.wbcsd.org.

Wong, L. C., \& Kleiner, B. (1994). Nepotism. Work Study, 43(5), 10-12. doi:10.1108/ EUM0000000004002.

Young, C. A., \& Corsun, D. L. (2010). Burned! The Impact of Work Aspects, Injury, and Job Satisfaction on Unionized Cooks' Intentions to Leave the Cooking Occupation. Journal of Hospitality \& Tourism Research, 34(1), 78-102. doi:10.1177/1096348009349816.

Zukauskas, P., \& Vveinhardt, J. (2009). Socio-Demographic Characteristics of Mobbing and Discrimination in Employee Relations. Transformations in business and economics, 8(3), suppl. A, 129-147.

Chief Researcher Jolita Vveinhardt, Ph.D. Lithuanian Sports University Institute of Sport Science and Innovations jolitaw@gmail.com

Regina Andriukaitiene, Ph.D. Lithuanian Sports University Faculty of Sports Education Department of Management, Economics and Sociology regina.andriukaitiene@gmail.com 


\title{
Abstract
}

\section{DIAGNOSTICS OF MANAGEMENT CULTURE IN ORDER TO IMPLEMENT THE CONCEPT OF A SOCIALLY RESPONSIBLE COMPANY: THE CASE OF A CONCERN}

\author{
Jolita Vveinhardt, Regina Andriukaitiene
}

While implementing corporate social responsibility (CSR) in practice, it is necessary to evaluate the management culture of the organization, which is the instrument and the indicator of the initial position of implementation the CSR. The article substantiates the level of the management culture and corporate social responsibility problems explored in the works of authors. The relatively great lack of scientific literature on the topic of management culture, therefore, this article presents the authors analysing the components of management culture. Theoretical and empirical research involves relatively different contexts of corporate social responsibility topics from managerial transformations to corporate social responsibility approach in the aspect of national traditions and international influences. The aim of this article is to determine the level of management culture in order to implement the conception of a socially responsible company in the case of manufacturing companies' group. So in order to implement the set aim the survey was carried out in 2013. The authors' formed the questionnaire 'Determination of management culture level for the implementation of the conception of a socially responsible company' and used it for the survey. The empirical study was carried out in one of the Eastern Europe manufacturing concerns registered in Lithuania. The concern wished to remain anonymous; and 885 employees worked in it during the investigation period, i.e. 91 percent of all employees. When presenting the results, the demographic characteristics of the respondents are detailed according to: company's group divisions, currently occupied positions, work experience, age, gender, education. The results of the empirical research show that management culture is related to the level of social responsibility perception within the organization. The reaction of the organization employees towards the management culture shows the directions of its changes.

Key Words: Management culture, social responsibility, corporate social responsibility.

JEL Classification: M120, M140.

DOI: 10.15240/tul/001/2016-3-010 